Matthias Freise*

\title{
Próba typologii podstawowych zagadnień komparatystycznych
}

\author{
http://dx.doi.org/10.12775/LC.2015.015
}

S t r e s z c z e ni e. Przedmiotem komparatystyki nie są substancje, lecz relacje. Relacje nie „istnieją", trzeba je łączyć. Cztery różne sposoby tworzenia relacji odpowiadają czterem podstawowym zagadnieniom komparatystyki. Porównanie semantyczne jest relacją obserwowaną w samym systemie literatury i symetryczną; porównanie funkcjonalne wykracza poza system literatury i też jest symetryczne; transfer kulturowy wykracza poza system literatury i jest relacją jednostronną, asymetryczną; wplyw literacki jest immanentny w systemie literatury i jednostronny. Dwie z tych możliwych form relacji traktują badane systemy kulturowe immanentnie, jedna tropi wędrówkę obrazów albo motywów, druga tworzy ekwiwalencje kulturowe. Pozostałe dwie formy relacji wykraczają poza system literatury i kultury, jedna ku społecznej funkcji literatury, druga w kierunku świata faktów i przedmiotów. Jednostronne formy relacji implikują następstwo tekstów, czyli relację syntagmatyczną. Symetryczne formy relacji implikują równoczesność - albo systemy literackie znajdują się naprzeciw siebie, albo ich ekwiwalencja jest podstawą dla typologicznego porównania. Wyliczenie możliwości badań komparatystycznych dokonane przez Wacława Borowego cierpi z powodu nierównej ich oceny. W artykule zademonstrowano, w jaki sposób są one równorzędne i jakie rezultaty się otrzymuje, zależnie od poziomu, na którym zadaje się pytanie.

S l ow a k l u c zowe : typologia; komparatystyka; Wacław Borowy; badanie funkcjonalne; badanie semantyczne.

A bstract. A typology of basic comparative issues. Comparative studies do not deal with objects, but with relations. Relations do not exist, they have to be established. On the basis of the four elementary forms of relation - unity, separation, dialogue and determination - there have

* Autor jest dyrektorem Instytutu Slawistyki Uniwersytetu Georga Augusta w Getyndze. Wykładał na uniwersytetach w Toruniu (UMK), Krakowie (UJ), Petersburgu (SpbGU) i Szanghaju (ECNU). Zajmuje się literaturą rosyjską XIX wieku, literaturą polską XX wieku oraz teorią literatury. Opublikował m.in. książkę Geschichtlichkeit im Werk von Czesław Miłosz (2014). Jest członkiem kapituły nagrody im. Samuela Bogumiła Lindego oraz Societas Jablonoviana. E-mail: mfreise@gwdg.de. 
been distinguished four basic forms of comparative studies. Semantic comparison is immanent to the literary system and mutual; functional comparison is also mutual but goes beyond the literary system; cultural transfer goes beyond the literary system but is unilateral; and literary influence is unilateral but immanent to the literary system. Two of these relations examine cultural or literary systems immanently - one traces the wandering of tropes and motives, the other reconstructs cultural interrelations. The other two forms of comparative studies go beyond literary and cultural systems, one in the direction of the social functions of literature, the other in the direction of facts and objects. The unilateral relations are based on succession in time, while the mutual forms imply simultaneity - either they are contrasted to one another with respect to their function, or they are put into a typological equivalence. Against this background, the article discusses Wackaw Borowy's description of different forms of comparative literature. While Borowy distinguishes "valid" and "invalid" forms of comparative studies, this article tries to demonstrate their equal epistemological value and to systematically arrange the different answers which can be expected from them.

Key words : typology; comparative studies; Waclaw Borowy; functional analysis; semantic analysis.

\section{Komparatystyka jako nauka o stosunkach}

omparatystyka należy do nauk dotyczących stosunków. Takimi naukami są też na przykład semiotyka (analizuje stosunek znakowy), psychologia (stosunek osobowy), socjologia (stosunki społeczne), teoria poznania (stosunek poznawczy), teologia (stosunek człowieka z Bogiem). Badanie stosunków zakłada, że analiza nie wychodzi od właściwości żadnego z uczestników relacji. Zamiast tego bada się charakter samego stosunku, jak gdyby stosunek istniał przed jego uczestnikami. Co to znaczy? Możemy rozumieć rzeczywistość jak zbiór substancji lub jak sieć stosunków. Filozof Ernst Cassirer mówi o pojęciach „substancji” $i$ „funkcji”. Pokazuje on, że z punktu widzenia funkcji relacje poprzedzają swoje poszczególne składniki. Dlatego, myśląc funkcjonalnie, nie możemy wyprowadzać relacji z cech „uczestniczących” w nich instancji². Logika pojęcia substancji i pojęcia funkcji różni się zasadniczo. Naukowe badania komparatystyczne powinny używać pojęć odnoszących się do relacji, ponieważ ich celem jest porównanie.

\footnotetext{
1 Por. E. Cassirer, Substanzbegriff und Funktionsbegriff, Berlin 1910 (wyd. polskie: Substancja i funkcja. Badania nad podstawowymi problemami krytyki poznania, tłum. P. Parszutowicz, Kęty 2008).

2 Ibidem, s. 445.
} 
Stosunki są zasadniczo ambiwalentne, bo mają - jak kij w przysłowiu - „dwa końce”. Dlatego nauki, które badają relacje, wymagają innych metod niż nauki, które ustalają jakieś właściwości przedmiotów. Stosunek nigdy nie zawiera jednej prawdy, ale co najmniej dwie. Kto kiedyś próbowal pośredniczyć w sporze małżonków, wie, o co tu chodzi. Dlatego w naukach o relacjach nie można używać dwuwartościowej logiki „tak albo nie”, „plus albo minus”. Badanie stosunków ma swoją logikę - logika „stosunkowa” jest inna niż logika klasyczna. Nauki o stosunkach mają badać same relacje, a nie uczestników tych relacji. Dlatego metody statystyczne, które uwzględniają tylko uczestników stosunku, ponieważ nie znają niczego oprócz przedmiotów, nie są tu odpowiednie. $Z$ tego powodu socjologia statystyczna i psychologia empiryczna, ściśle mówiąc, nie są naukami o relacjach. Rozumieją ludzi, ale nie rozumieją stosunków.

Logika formalna do badania przedmiotów używa rachunku zdań, który dotyczy substancji, natomiast do badania stosunków używa rachunku predykatów, który dotyczy relacji. Logika predykatów jest wielowartościowa. Ale jakie wartości potrzebne są do rozumienia stosunków? Z punktu widzenia logiki stosunek może przybierać cztery różne wartości: 1) A istnieje niezależne od B; 2) A jest identyczne z B; 3) A hierarchicznie rządzi B; 4) A i B są dla siebie funkcjami, tj. wartość A zależy od wartości B i na odwrót. Dlatego proponuję w badaniu stosunków generalnie wychodzić od czterech zasadniczych możliwości struktury relacji: odgradzanie się, zlanie się, formowanie hierarchii (dominacja/podporządkowanie) i nawiązanie dialogu. Te możliwości, pojawiające się w każdej dziedzinie relacyjnej, nie wynikają z czterech kategorii poznania Arystotelesa i Kanta ani z innych kategorii filozoficznych. Na odwrót, to logika stosunków leży u podstaw filozoficznych koncepcji, które dotyczą relacji (na przykład kategorie poznania opisują stosunki poznawcze).

Również komparatystyka jest nauką o stosunkach. Trzeba ją jednak odróżnić od także relacyjnego badania intertekstualności. Badanie intertekstualności zajmuje się stosunkami między pojedynczymi tekstami niezależnie od ich pochodzenia, podczas gdy komparatystyka jest badaniem stosunków między systemami literackimi ponad granicami narodowymi. Co prawda, nie zawsze różnica ta jest wyraźna. Na przykład wpływ literacki zwykle rozumiany jest jako oddziaływanie konkretnego tekstu wzorca na tekst, który ze względu na tę relację jest wtórny. Dla komparatystyki wpływ literacki jest fenomenem kulturowym. Jedna kultura, na przykład antyk rzymski, staje się wzorem dla innej kultury, na przykład dla renesansu europejskiego. Ale demonstrować ten fenomen kulturowy można tylko na przykładach pojedynczych tekstów, obrazów, budynków. Mimo to pozostaje fundamentalna różnica - podstawą badania intertekstualności jest tekst, podstawą badań komparatystycznych jest system literacki jako część kultury. Komparatystyka bada stosunki kulturowe.

Postaram się dalej wytłumaczyć, jakie konsekwencje dla badań komparatystycznych wynikają z tezy, że komparatystyka jest nauką dotyczącą relacji. Cztery logiczne możliwości w każdej „dziedzinie relacyjnej” można rekonstruować w ten sposób, że szukamy fundamentalnych sprzeczności, które kształtują poszczególne stosunki, w naszym przypadku - relację między systemami literackimi. W komparatystyce do takich sprzeczności należy to, że z jednej strony słowo „komparatystyka” pochodzi o łacińskiego comparare, to znaczy „porównywać”, ale z drugiej strony komparatystyka często wcale nie porównuje. „Wpływologia" i badania nad transferem kulturowym nie porównują w ścisłym sensie, a mimo to są zaliczane do badań komparatystycznych. Trzeba się zastanowić, jaka jest zasadnicza różnica między komparatystyką nieporównującą a porównującą. 
Wpływ i transfer kulturowy są stosunkami jednostronnymi. W wypadku wplywu kultura pierwotna oddziałuje na kulturę pochodną. Również transfer kulturowy dokonuje się w kierunku od kultury A do kultury B, w jedną stronę. Między wpływem literackim a transferem kulturowym istnieje jednak zasadnicza różnica. Badacz transferu kulturowego patrzy na swój materiał ściśle empirycznie. Empirycznie można stwierdzić, czy w określonym czasie i w określonej przestrzeni albo znajdowały się jakieś realne przedmioty, na przykład książki, albo odbyły się jakieś realne zdarzenia, na przykład przedstawienia teatralne. Wzorem badań transferu kulturowego są archeologia i badanie tzw. kultury materialnej, ustalające, że wtedy było to, a wtedy było tamto. Badacz transferu kulturowego patrzy wyłącznie na fakty albo na przedmioty, które mogą być związane między sobą tylko w jeden sposób: kauzalnie.

Wpływ literacki natomiast przyjmuje za zasadę nie kauzalność, lecz logikę. Co prawda, lektury autora mają określone rezultaty. Dla uzasadnienia wpływu potrzebny jest dowód, że autor rzeczywiście czytał utwór, który mógłby wywrzeć na niego wpływ. Z punktu widzenia określonego wpływu nowy utwór zależy od starego, podporządkowuje się wzorcowi. Nie można jednak dowieść, że zastosowanie jakiegoś motywu albo symbolu jest ścisłym skutkiem uprzedniej lektury konkretnego tekstu. Wpływ polega wyłącznie na wewnętrznej logice utworów wchodzących ze sobą w relację, bo przyczyna decyzji autora, na przykład o użyciu jakichś chwytów literackich, nie jest dostępna badaniu.

Dlatego dla badaczy transferu kulturowego, takich jak Michel Espagne z École Normale Supérieure w Paryżu ${ }^{3}$, założenia wpływologii są spekulacjami. Zamiast tego komparatystyka powinna i musi się ich zdaniem ograniczyć do empirycznie bezpiecznego obszaru badań na podstawie „twardych faktów”. Tylko wtedy potwierdzenie przeniesienia do innej kultury motywu, metody literackiej, postaci czy całego tekstu jest możliwe. Ale jeżeli wpływologia nie jest $\mathrm{w}$ stanie dowieść faktu przeniesienia motywu, to transferologia z kolei nie może udowodnić wejścia faktu w strukturę utworu. Jeśli na podstawie indywidualnych egzemplarzy książek, malowideł, listów lub nawet włosów leżących między stronicami można wykazać, że Maria Wirtemberska przed napisaniem swojej Malwiny miała w rękach, powiedzmy, Emmę Jane Austen, to jeszcze nie znaczy, że na przykład przejęła z tej powieści technikę literacką mowy pozornie zależnej. Brakuje bowiem kompletnego łańcucha przyczynowego, którego ślady zacierają się przy przejściu przez ludzką świadomość. Odkrycia rozumu mogą również powstać niezależnie od siebie i w różnych miejscach, a prawo autorskie nie obejmuje metod i motywów literackich, każdy bowiem może po nie sięgać bez żadnych konsekwencji.

Porównanie natomiast polega na stosunkach symetrycznych, wzajemnych - to wynika już z rdzenia „równ-”. W komparatystycznym porównaniu też istnieją dwie zasadnicze formy: porównanie funkcjonalne i porównanie semantyczne. W życiu codziennym porównanie zawiera zadanie wyboru, na przykład: zerwać to czy tamto jabłko. Od razu widać, że porównanie dokonuje się tu na podstawie funkcji przedmiotów. Wybiera się to, co lepiej się nadaje do spełnienia jakiejś funkcji, na przykład do jedzenia. Funkcja jedzenia nie jest zawarta w istocie jabłka. To dotyczy także porównań funkcjonalnych w systemie literatury. Ponieważ sama literatura nie może być swoją własną funkcją, jej funkcja wykracza poza dziedzinę systemu literatury. Do czegokolwiek poza sobą samą literatura się nadaje, to wła-

3 Por. M. Espagne, Les transferts culturels franco-allemands, Paris 1999. 
śnie jest jej funkcją. Komparatystyka funkcjonalna bada, jakie funkcje system literacki pełni $\mathrm{w}$ różnych społeczeństwach, w różnych kulturach.

Porównanie semantyczne z kolei zestawia różne systemy literackie. Porównanie takie ogranicza się do sfery literatury. Formuje ono między systemami ekwiwalencję, a ekwiwalencje wywołują procesy semantyczne. Porównanie semantyczne opiera się na ekwiwalencji między literaturami, dlatego mimo że dotyczy ono zewnętrznych relacji literackich, trzyma się, tak jak badanie wpływu, wewnętrznej struktury utworów. Porównanie funkcjonalne natomiast, tak jak badanie transferu kulturowego, przekracza granice tej struktury, wykracza poza nią w kierunku użytkowników literatury, jak badanie transferu kulturowego - w kierunku kontaktów rzeczywistych (dlatego że w tym wypadku decydujące jest przemieszczanie się - książek, rękopisów, zespołów artystycznych, informacji albo samych pisarzy).

Mamy więc do czynienia z czterema aspektami komparatystyki: transfer kulturowy, wpływ, porównanie funkcjonalne i porównanie semantyczne. Transfer kulturowy jest jednostronny, ale wykracza poza granicę systemu literackiego. Wpływ też jest jednostronny, lecz nie wykracza poza granicę systemu literackiego. Porównanie funkcjonalne jest relacją symetryczną i wykracza poza granicę systemu literackiego. Wreszcie porównanie semantyczne też jest symetryczne, ale nie wykracza poza granicę systemu literackiego.

\section{Komparatystyka semantyczna}

Obiekty, które chce się porównać na poziomie semantycznym, powinny być w stosunku do siebie w pewnej relacji. Do nawiązania relacji wymagany jest po pierwsze postulat jakiejś cechy wspólnej, leżącej u podstaw tekstów. Ta wspólna cecha może być raczej ogólna albo raczej specyficzna. Zwykle przypuszczamy, że porównanie semantyczne oparte na zasadzie zbyt ogólniej nie może przynieść wyrazistego rezultatu. Jednak to zależy od odległości zjawisk literackich. Przy wielkiej odległości czasowej albo przestrzennej nawet dostrzeżenie ogólnych cech wspólnych może dać wyraziste rezultaty. Porównanie semantyczne oparte na zasadzie cech wspólnych rekonstruuje w porównywanych utworach „autofunkcję” (w rozumieniu Tynianowa) wybranych chwytów ${ }^{4}$. Ale to, co w porównaniu pojedynczych utworów jest autofunkcją, jednocześnie jest „synfunkcją” całego systemu literackiego. To znaczy, że porównanie semantyczne może mieć dwa różne cele: albo chodzi o zrozumienie, jaka jest różnica semantycznej funkcji wybranego chwytu w porównywanych utworach (autofunkcja), albo o zrozumienie systemów literackich jako takich (synfunkcja). Do osiągnięcia tego ostatniego celu nie wystarczy stwierdzenie, że jedno zjawisko literackie „różni się" od drugiego. Potrzebna jest rekonstrukcja całego systemu ekwiwalencji między porównywanymi utworami. Ponieważ włączenie utworu w system ekwiwalencji jest tożsame z jego formą, porównanie semantyczne może wychodzić tylko od tej formy.

Poszczególne utwory literackie stanowią elementy systemu literackiego. Każdy z utworów ma w nim swoją tożsamość, regulowaną przez korelację funkcji konstrukcyjnych. Trze-

\footnotetext{
${ }_{4}^{4}$ Por. J. Tynianow, O ewolucji literackiej, tłum. A. Pomorski, [w:] idem, Fakt literacki, wyboru dokonała E. Korpała-Kirszak, Warszawa 1978. Autofunkcja chwytu literackiego jest dla Tynianowa tym, co ten chwyt wnosi do semantyki pojedynczego utworu.

${ }_{5}^{5}$ Synfunkcja chwytu literackiego jest dla Tynianowa tym, co ten chwyt wnosi do systemu literackiego.
} 
ba mieć przy tym na względzie, że treściowość każdego formalnego elementu literatury, zgodnie z tezą Jana Mukařovskiego, dotyczy nie tylko konstrukcyjnej funkcji elementów jednego utworu, ale też literackiej funkcji utworu w systemie literatury. To znaczy, że rekonstruowany dzięki porównaniu semantycznemu system literacki też ma swoją semantykę. Jeżeli jednak badamy „intertekstualność” w sensie nadanym temu terminowi przez Julię Kristevę, czyli jako przepływanie głosów przez mnóstwo tekstów, wtedy mylimy badanie intertekstualności z komparatystyką, to jest system literatury z systemem utworu albo autofunkcję utworu z jego synfunkcją.

Weźmy na przykład klasyczny dla komparatystyki motyw protestu przeciw autokracji cara w Jeźdźcu miedzianym Puszkina i w Dziadach Mickiewicza. Na poziomie autofunkcji, czyli intertekstualności, motyw ten rozumie się tylko jak odpowiedź Puszkina na prowokację Mickiewicza. Dopiero dzięki porównaniu na poziomie synfunkcji, a więc komparatystyki, semantyka ekwiwalencji między tekstami przemawia do nas, odsłaniając przynależność obu utworów do romantycznego paradygmatu edypalności, to jest do określonego systemu literackiego ${ }^{6}$.

Tak zatem semantyczne porównanie zbliżonych przedmiotów estetycznych ze względu na postaci, język i przestrzeń jest właściwie komparatystyką szerszych kontekstów kulturowych, badającą relacje narodów, języków, gatunków czy form artystycznych. W komparatystyce zakres powiązań poszczególnych przedmiotów estetycznych jest więc o wiele większy niż w badaniu intertekstualności. Komparatystyka zakłada, że poza granicami jednego systemu literackiego czy obszaru kulturowego można ustalić parametry albo paradygmaty, które same w sobie są relatywnie homogeniczne i w związku z tym zauważalne. Dopiero w ich kontekście porównanie komparatystyczne zyskuje wartość poznawczą.

\section{Związek czterech aspektów komparatystyki z innymi typologiami stosunków}

W dziele Czworaki korzeń zasady racji dostatecznej Arthur Schopenhauer wyróżnia cztery podstawowe formy relacji: zasadę racji bycia, zasadę przyczynowości, zasadę motywacji oraz zasadę racji poznania ${ }^{7}$. Po pierwsze, każde powiązanie można rozumieć jako relację przyczynową. Relacja ta w obecnym modelu wiedzy zajęła miejsce najwyższe rangą. Pod względem semiotycznym przyczynowość łączy desygnaty. Nazywam ją historyczną, bo kieruje się kolejnością desygnatów w czasie. Po drugie, każde powiązanie można też rozumieć jako relację techniczną. Ta relacja jest dostępna przez zastosowanie immanentnej analizy zjawiska. Schopenhauer nazywa to rozumienie „racjonalnym”. Opiera się ono na logice. Pod względem semiotycznym połączone są tutaj elementy znaczące. Po trzecie, każdą relację można rozumieć finalistycznie - jako subiektywny związek motywacji. Analizę tak ujętych

- Por. M. Freise, Эдипальный бунт в польском и русском романтизме, [w:] Polska - Rosja: dialog kultur („Studia Rossica” t. 22), red. A. Wołodźko-Butkiewicz, L. Łucewicz, Warszawa 2012.

7 A. Schopenhauer, Czworaki korzeń zasady racji dostatecznej, tłum. J. Marzęcki, Kęty 2003. 


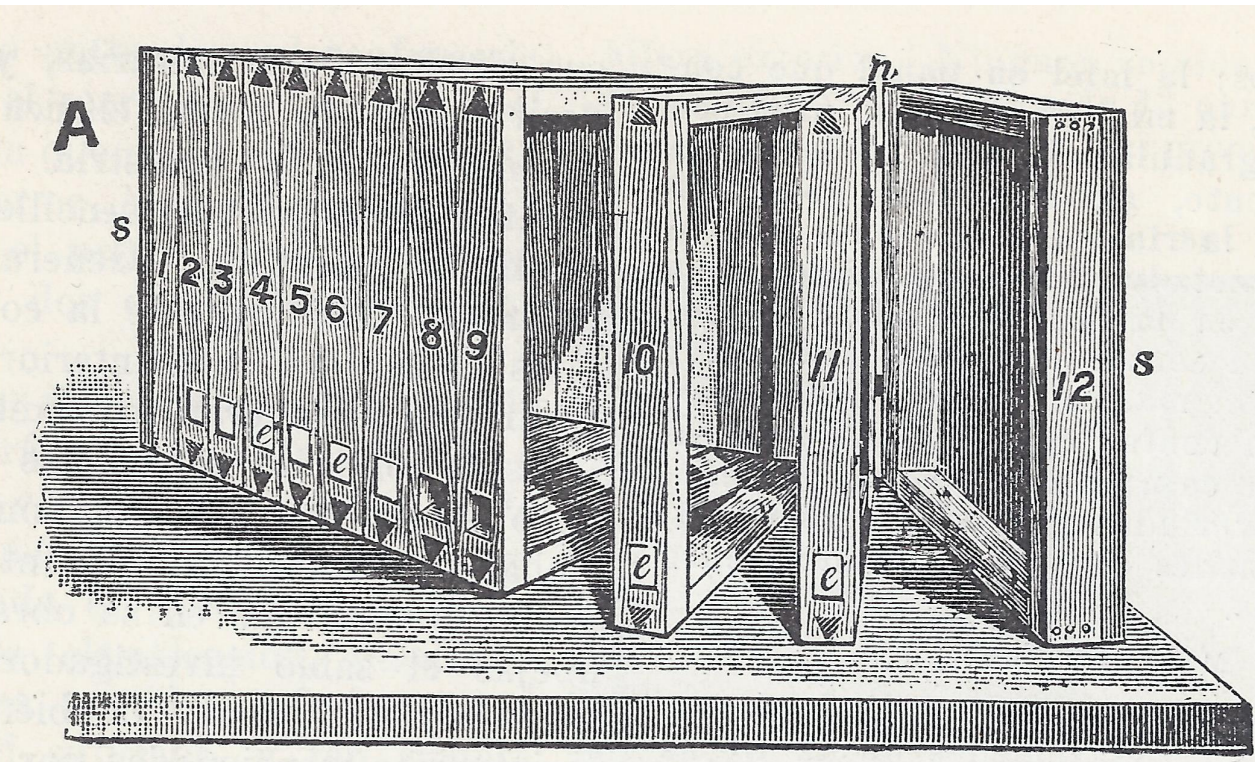

relacji umożliwiają psychologia i antropologia filozoficzna. Takie relacje nazywam filozoficznymi. Pod względem semiotycznym połączone są tutaj elementy znaczone. Poza tym spotykamy się ze światem, zgodnie z zasadą racji bycia, także kulturowo. Pod względem semiotycznym tutaj z kolei zostają ze sobą powiązane znaki. Według Schopenhauera ta właśnie zasada łączenia jest pierwotna.

Bez logiki, bez przyczynowości i bez motywacji można nadal w jakiś sposób egzystować, ale bez pierwotnie doświadczonego połączenia z zasadą racji bycia w ogóle nie można dostrzec w świecie żadnych relacji ${ }^{8}$. Zasada racji bycia jest asocjacją. Zajmowała ona najwyższe miejsce w okresie archaicznym, w szamanizmie i totemizmie, nie jest jednak zasadą „przestarzałą” czy „zapomnianą”, lecz w dalszym ciągu aktywną.

Nowoczesną typologią relacji jest system teoretyczny AGIL amerykańskiego socjologa Talcotta Parsonsa9. Parsons systematyzuje podstawowe funkcje, dzięki którym trwa każdy system społeczny. Wyróżnił on cztery funkcje społeczne, rozmieszczając je w kwadratowej strukturze czterech systemów: systemu zachowania, systemu osobistego, systemu kulturowego i systemu społecznego. System zachowania zapewnia osiąganie celów (goal-attainment), system osobisty zapewnia przystosowanie (adaptation). Oba są aktywnie-zmieniające. System społeczny zapewnia integrację (integration), a system kulturowy podtrzymywanie wzorów (latency). Oba są pasywnie-podtrzymujące. Adaptacja i podtrzymywanie wzorów to, według Parsonsa, funkcje „instrumentalne”, ponieważ są narzędziem dla innych celów, podczas gdy osiąganie celów i integrację nazywa on funkcjami „konsumpcyjnymi”, gdyż tworzą bezpośrednie korzyści. Ta ostatnia dychotomia jest trudna do zrozumienia. Sensowniejsze byłoby tutaj następujące rozróżnienie. Istnieją, po pierwsze, funkcje

${ }^{8}$ Por. M. Freise, Vier Weisen nach dem Text zu fragen, [w:] Finis coronat opus. Festschrift für Walter Kroll zum 65. Geburtstag, red. V. Bockholt, M. Freise, W. Lehfeldt, P. Meyer, Göttingen 2006, s. 75-76.

9 T. Parsons, Szkice z teorii socjologicznej, tłum. A. Bentkowska, wstęp H. Białyszewski, Warszawa 1972. 
„syntagmatyczne”, które wymagają pewnej sekwencji czasowej. Takimi funkcjami są osiąganie celów i integracja wewnętrzna. Aktywne zarządzanie owymi sekwencjami czasowymi stanowi określenie celów, pasywne radzenie sobie z nimi to integracja nowego. Z drugiej strony istnieją funkcje „paradygmatyczne”, jak adaptacja i podtrzymywanie wzorów, które wymagają równoczesności. Bierną równoczesność kształtuje podtrzymywanie wzorów, aktywną - adaptacja.

Jak mają się te typologie filozoficzne i socjologiczne do typologii badań komparatystycznych? Logika relacyjna powinna w nich być tego samego rodzaju. Ponieważ każdy system społeczny jest definiowany przez powiązania i granice ${ }^{10}$, to można argumentować również odwrotnie, że każde kulturowe porównanie może zostać podporządkowane czterem możliwym funkcjom społecznym.

Tabela 1. Czworaka struktura komparatystycznego łączenia

\begin{tabular}{|c|c|c|c|c|}
\hline $\begin{array}{c}\text { Racja dostateczna } \\
\text { według } \\
\text { Schopenhauera }\end{array}$ & $\begin{array}{c}\text { Forma } \\
\text { intertekstualności }\end{array}$ & $\begin{array}{c}\text { Badanie } \\
\text { komparatystyczne }\end{array}$ & Funkcja społeczna & Logika relacji \\
\hline egzystencjalna & palimpsest & $\begin{array}{c}\text { porównanie } \\
\text { semantyczne }\end{array}$ & podtrzymywanie & A U B \\
\hline finalistyczna & dialog & $\begin{array}{c}\text { porównanie } \\
\text { funkcjonalne }\end{array}$ & integracja & A $\leftrightarrow$ B \\
\hline przyczynowa & naśladownictwo & transfer kulturowy & podążanie za celem & A B B \\
\hline logiczna & aluzja & wplyw & dopasowanie & A II B \\
\hline
\end{tabular}

Funkcje i formy w żadnym szeregu tej tabeli nie są identyczne. Istnieją między nimi tylko pewne analogie, ponieważ pochodzą z jednej formy logiki stosunków. Różnice między nimi wynikają przede wszystkim z różnego zakresu stosowania. Na przykład to, co z punktu widzenia intertekstualności wykracza poza granicę, mianowicie granicę tekstu (aluzja), z punktu widzenia komparatystyki zostaje w swej sferze, mianowicie w sferze systemu literackiego.

Istnienia żadnej z tych czterech form relacji nie da się w ścisłym sensie udowodnić. Kulturowe powiązania są zbyt złożone. Niemniej jednak możemy zarejestrować w różnych tekstach, w różnych czasach i w różnych kulturach narodowych te same lub podobne schematy, przedmioty, ciągi zdarzeń i inne wyróżniające się elementy. Podobnie w przyrodoznawstwie dla wszystkich wyróżniających się elementów wolno nam postulować o „rację dostateczną”. Wszelkie odchylenie od bezkształtnego „białego szumu” jest w kulturze naładowane semantycznie. Formacje chmur, marzenia albo konstelacje gwiezdne, z przyczynowego punktu widzenia, są tylko przypadkowościami. Aleksander Wat mówi w Moim wieku: „Wbrew Freudowi twierdzę, że większa część naszych marzeń sennych to kaprysy wyobraźni, takie jak kaprysy chmur. Jednak czasem masz we śnie świadomość, że ten sen jest znaczący. Nie mówię: proroczy, ale znaczący. [...] Tak samo z wydarzeniami, ze znakami" ${ }^{11}$.

\footnotetext{
10 Zob. N. Luhmann, Soziale Systeme. Grundriss einer allgemeinen Theorie, Frankfurt am Main 1984.

11 A. Wat, Mój wiek. Pamiętnik mówiony, wyd. 2 popr., cz. 2, Londyn 1981, s. 196.
} 
W istocie kultura polega na tym, żeby fanaberiom wyobraźni czy przyrody nadać znaczenie. Stają się znakami, zdarzeniami, nabywają znaczeń, a te znaczenia następnie stają się kulturową rzeczywistością. Tak funkcjonuje, postrzegając rzecz filozoficznie, także przyczynowość. Przyczynowości nie dostrzegł jeszcze nikt, widoczne są tylko zagęszczenia zjawisk, z których wnioskujemy o przyczynowości. Ale moglibyśmy wywnioskować z nich też inne formy relacji.

Co to oznacza dla komparatystyki? Komparatystyczne porównanie też musi mieć wystarczające podstawy. Ponieważ podstawy te nie są obecne, ale wywołane, tj. muszą od czegoś pochodzić, zadaniem badań komparatystycznych jest wywodzić odpowiednie powody dostateczne dla zaobserwowanych wyróżniających się podobieństw, przeciwieństw albo wzajemnych przynależności różnych elementów. Sam komparatysta staje się zatem kulturowym aktorem. Nie może wyjść z tej roli, ponieważ znaczenie jest zawsze „znaczeniem dla kogoś”, tj. bez stania się samemu pewną instancją, dla której uderzające podobieństwo lub zbieżność staje się znaczeniem, komparatysta nie może w żaden sposób znaleźć odpowiedniej podstawy dla połączenia danych zjawisk. Ponadto trzeba przekazać intersubiektywnie przekonujące argumenty przemawiające za porównaniem tych wyróżniających się elementów. Ponieważ zjawisk kulturowych nie da się reprodukować w drodze eksperymentu, może tutaj wchodzić w grę tylko strategia maksymalnie przekonującej argumentacji. Uzasadnienie trafności porównań można wzmocnić przez sensowne przyporządkowanie zaobserwowanych wyróżniających się podobieństw, przeciwieństw etc. innym podobieństwom, przeciwieństwom etc. Podobnie jak wystąpieniu określonej temperatury powietrza możemy zawsze przypisać inne parametry, takie jak światło słoneczne, kierunek wiatru, ciśnienie powietrza, temperatura wody i gleby, zawartość dwutlenku węgla w atmosferze i tak dalej, tak też badania przedstawiają szczególne zagadnienia literatury porównawczej przez powiązanie ich $\mathrm{z}$ dodatkowymi zjawiskami, takimi jak podobieństwa modeli relacji kulturowych, ich przeciwieństwa itp.

\section{Komparatystyczne badanie wpływu}

Komparatystyczne badania wpływu odpowiadają, jak już widzieliśmy, związkowi logicznemu według Schopenhauera. Z perspektywy wewnętrznej logiki późniejszy tekst jest uzależniony od tekstu wcześniejszego. Ale gdy przyjrzymy się bliżej tej zależności, to ujawni się istotna różnica, którą należy wziąć pod uwagę. Mogę posłużyć się jedną ze znanych literackich technik któregoś z wcześniejszych autorów, nie będąc ściśle uzależnionym od tego właśnie autora. Obrazy, wyrażenia, gatunki ukształtowały się i będą świadomie lub nieświadomie wykorzystywane przez kolejne pokolenia. Dlatego Wacław Borowy wyróżnia dwa sposoby rozumienia wpływu i zależności ${ }^{12}$. Nazywa je rozumieniem psychologicznym (rozdziały 2-6 jego monografii) i socjologicznym (rozdział 9). Za tymi terminami kryje się także rozróżnienie pomiędzy wzorcem wcześniejszego tekstu (który jest „psychologiczny”) a dostępem do określonych gatunków i obrazów („socjologicznych”), takich jak na przykład słowik i skowronek w amerykańskiej poezji w pierwszej połowie XIX wieku. Żadnego

12 W. Borowy, O wpływach i zależnościach w literaturze, Kraków 1921. 
z tych ptaków nie znajdziemy na kontynencie amerykańskim, ale w poezji Szekspira, Wordswortha, Keatsa i Shelleya posiadają one ugruntowaną symbolikę, z której amerykańscy poeci nie chcieli zrezygnować. Jest to więc pytanie o technikę literacką lub o retorykę. Nie każdy, kto posługuje się sonetem, jest uczniem Petrarki. Ten jednak, kto sięgnie po sonet, w większości przypadków zmodyfikuje ten gatunek, przedstawi go w innym świetle, przyporządkuje mu nowe artystyczne cele. Tutaj dominuje ciągła przemienność automatyzacji i udziwnienia (uniezwyklenia), którą rosyjscy formaliści uznali za siłę napędową historii literatury.

Ta zmienność tak naprawdę nie może być opisana jako zależność przyczynowa. Zasadą rządzących nią relacji, zgodnie z myślą Schopenhauera, także nie jest przyczynowość, lecz logika, ponieważ nie literackie modele są tutaj decydujące, tylko wewnętrzna funkcjonalność zastosowanych chwytów literackich. Teksty dające się porównać znajdują się wobec siebie w pewnej relacji dzięki użyciu odpowiednich środków retorycznych. Ich wewnętrzna logika buduje podstawę do porównania. Można w ten sposób ustalić, jakie zostaną osiągnięte efekty dzięki wykorzystaniu takich środków w różnych kontekstach. Tej logice odpowiada społeczna funkcja adaptacji. System literacki przystosowuje się do zmieniających się warunków przez udziwnienie i przekształcenie metod literackich. Przez to kształtuje się historia gatunku, która analizowana była szczególnie w formalizmie. W odróżnieniu od tej logicznej relacji, kulturowa przyczynowość (w terminologii Borowego „wpływ psychologiczny”) spełnia społeczną funkcję integracji, ponieważ w ramach badań wpływów i zależności późniejsi autorzy zostają włączeni do istniejącego systemu kulturowego.

\section{Finalistyczność komparatystycznych badań funkcjonalnych}

Jeśli prześledzimy Schopenhauerowski schemat możliwych relacji, to finalistycznej racji dostatecznej musi odpowiadać jakiś zamiar, cel, który objawia się w tekstach. Odpowiednio, społecznej funkcji osiągania celów powinno zostać przypisane pytanie komparatystyczne. Z punktu widzenia komparatystki nie chodzi o to, żeby po prostu zrekonstruować zamierzenia autora pojedynczego tekstu. Chcemy przecież porównać. Jeśli jakiemuś tekstowi (zamiast realnemu autorowi) przypiszemy pewną funkcję, to w ujęciu komparatystycznym nie może być ona osobistą funkcją, którą tekst ma dla jego autora. Porównanie funkcjonalne powinno konfrontować funkcje tekstów w ich systemach literackich i poza nimi. Te systemy interferują ze sobą tak jak różne światopoglądy. Wprawdzie tekst o wartości artystycznej nie ma funkcji wyrażania jakichkolwiek poglądów, wszelako konkuruje on $\mathrm{z}$ innymi genezami sensu, z innymi modelami świata, z innymi powiązaniami. Wtedy pojawia się „dialog kultur”.

Procesy te są szczególnie pouczające dla komparatystyki, ponieważ pokazują, które teksty o wartości artystycznej w danej epoce lub w danym obszarze kulturowym nadają się do połączenia z tekstami innej epoki lub innego obszaru kulturowego, tj. z jakim okresem lub przestrzenią poszukiwany jest dialog. W samym zaś dialogu z tekstami z innego czasu i z innej przestrzeni kształtuje się tożsamość kulturowa. Za każdym razem specyfika innego miejsca, innego czasu zostaje dostrzeżona, a tym samym jest kulturowo skuteczna. 


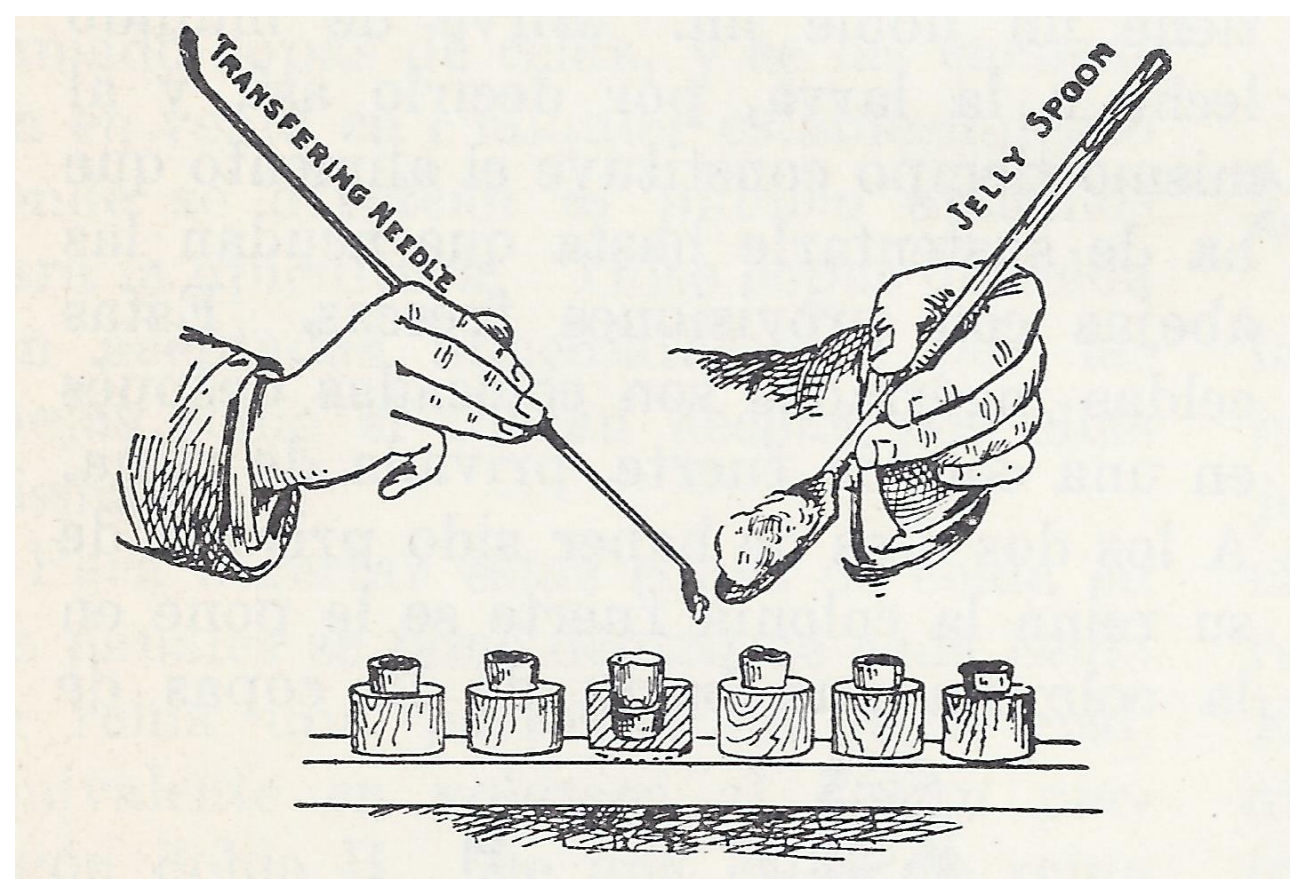

Szczególnie ciekawymi przykładami takiego dialogu są teksty religijne, których późniejsze odniesienia wskazują na wiele wcześniejszych. Filozof Arthur Drews wykazuje, że wszystkie ważne elementy narracyjne Nowego Testamentu można znaleźć już we wcześniejszych tekstach egipskich, w mitologii grecko-rzymskiej i bliskowschodniej ${ }^{13}$. Niezależnie od tego, czy za tą narracją stoi „prawdziwy” Jezus, można zadać szereg pytań. Czy Nowy Testament jest tylko zestawieniem dawniejszych mitów? Albo odrzuca wszystkie te mity? Jakie wartości poznawcze posiadają te genetyczne wnioski wyciągnięte z porównań? Czy dewaluują późniejszy tekst? Teologia znalazła własną odpowiedź na to pytanie już we wczesnym chrześcijaństwie: Nowy Testament nie został skompilowany, ale wręcz przeciwnie, wcześniejsze mitologiczne i filozoficzne teksty „przepowiadają” Mesjasza, a późniejszy tekst o pojawieniu się Mesjasza uzasadnia teksty wcześniejsze w funkcji etapów historii zbawienia. Te „biblijne aluzje” były wykorzystywane szczególnie do uzasadnienia Starego Testamentu, ale także starożytnych tekstów filozoficznych, przez Nowy Testament. Romanista i komparatysta Erich Auerbach przeniósł tę strukturę do „profanum” historii literatury. Mówi on o „prefiguracjach” w odniesieniu do diachronicznych relacji między tekstami literatury ${ }^{14}$. Ten dialog jest dialogiem różnych funkcji. Nowy Testament radykalnie zmienił przeznaczenie starszych od niego mitów, przydał im zupełnie nową funkcję kulturową. Dlatego wcześniejsze motywy i wzorce narracyjne okazują się prefiguracjami późniejszych, tj. nie można ich zrozumieć bez odwołania się do ich późniejszej wartości dla innych tekstów (oczywiście rozumianej już nie w odniesieniu do historii zbawienia, lecz w odniesieniu kulturowym).

\footnotetext{
13 A. Drews, Die Christusmythe, Jena 1909.

${ }^{14}$ E. Auerbach, Figura, "Archivum Romanicum” 1938, t. 22, s. 436-489.
} 
Komparatystyka w ujęciu Auerbacha rozumiana jest jako świecka historia zbawienia. Dzięki temu Auerbach rozwiązuje dwa problemy diachronicznej komparatystyki. Po pierwsze, odchodzi od dualistycznej opozycji pomiędzy „oryginalnością” a „zależnością”, gdyż kompromisy w rodzaju stwierdzeń: „nieco zależne” lub „częściowo oryginalne” mają małą wartość naukową. Po drugie, ponieważ wcześniejszy tekst jest oceniany w świetle interpretacji przez tekst późniejszy, wydaje się, że formuje się między nimi hierarchia ${ }^{15}$. Czyniąc tekst wcześniejszy swoją prefiguracją, późniejszy tekst pozornie „podbija” wcześniejszy tekst, który w tej relacji pozostaje bierny, on jakby „przygotowuje” tekst późniejszy. Ale Auerbach nie rozumie prefiguracji w ten sposób. Unika on wartościującej hierarchii między pre- i post-tekstem. Tekst wcześniejszy zachowuje - a późniejszy tekst osiąga - swoją kulturową wartość dzięki wzajemnemu układowi prefiguracji, ponieważ przez tę konstelację są one zdolne zarówno odnosić się do siebie i przekształcać nawzajem, jak i uznawać wzajemnie swoją kulturową produktywność. Wtedy teksty różnych czasów „nie okradają się” nawzajem. W wyniku prefiguracji nie tylko tekst wcześniejszy wspiera cele kulturowe tekstu późniejszego, lecz także na odwrót - tekst późniejszy wspiera cele kulturowe poprzedniego, ponieważ teksty integrują się wzajemnie. Formuje się między nimi dialog. Późniejsze teksty są w stanie przejąć teksty wcześniejsze i je opracować, jeśli rozpoznają i akceptują ich kulturową funkcjonalność. Czynią to dzięki temu, że sięgają po nie, nie imitując ich przy tym. Różne epoki i okresy nie kwestionują swojej funkcjonalności, lecz nadają ją sobie wzajemnie w drodze dialogu, przez to, że motywy i schematy narracyjne każdego z nich odwołują się do siebie nawzajem.

\section{Porównanie semantyczne}

Ostatnia racja wystarczająca relacji, racja egzystencjalna, którą Schopenhauer nazywa zasadą racji bytu, odpowiada związkowi, który nie istnieje na poziomie tekstu, lecz tylko na poziomie kultury. Na podstawie tego związku możliwa jest komparatystyka typologiczna. Istnieje on jedynie w indywidualnej lub zbiorowej świadomości porównującej, która odkrywa takie analogie lub przeciwieństwa między tekstami, dla których w immanencji poszczególnych tekstów nie ma żadnego uzasadnienia. Taki związek, który w ścisłym tego słowa znaczeniu nie jest zamierzony przez sam tekst, określa Borowy we wspomnianej pracy jako „błąd metodologiczny” ${ }^{16}$. Jest on jednak kulturową rzeczywistością, i to niemało znaczącą, ponieważ odpowiada najgłębszej kulturowej podstawie systemu społecznego, jego podstawowemu porządkowi.

Uderzająca analogia lub uderzające przeciwieństwo na poziomie kulturowym uzasadniają bardziej głębokie powiązanie niż konkretne wypowiedzi artystyczne, niż konkretne zastosowanie artystycznych środków aluzji. Ta zależność odnosi się do pierwotnego związku ze światem, poprzedzającego wszystkie intencje, do związku, który jako pierwszy określa dla

15 To odpowiada modelowi diachronicznej intertekstualności, tak jak Harold Bloom przedstawia go w swojej najgłośniejszej książce The Anxiety of Influence (wyd. polskie: Lęk przed wpływem. Teoria poezji, tłum. A. Bielik-Robson, M. Szuster, Kraków 2002): aby z naśladowcy swoich poprzedników stać się niezależnym, suwerennym artystą, muszę „zdegradować” swój „wzorzec” do rangi mego poprzednika. Dialog pomiędzy tymi instancjami jak równego $z$ równym nie jest u Blooma przewidziany.

${ }^{16}$ W. Borowy, op. cit., s. 67-68. 
nas afektywną jedność świata i który udostępnia nam świat jak kosmos. Komparatystyka nie powinna obawiać się badania także tych związków. Właśnie na tym poziomie staje się ona kulturoznawstwem, ponieważ porównawcze studia kulturowe nie są w stanie w inny sposób ustalić relacji pomiędzy różnymi przestrzeniami lub czasami. Bez analogii i przeciwieństw, tj. bez ekwiwalencji w rozumieniu Jakobsona, kulturoznawstwo porównawcze musi się ograniczyć do ustalania „różnic”. Stwierdzenie, że X jest inne niż Y, nie formuje jednak żadnych korelacji i dlatego nie umożliwia żadnych uogólnień. Natomiast kulturowa komparatystyka, która ustanawia ekwiwalencje między tekstami, które bezpośrednio ani nie odwołują się do siebie wzajemnie, ani nie stykają się, ani nie należą do tych samych gatunków literackich, może być podstawą do porównań typologicznych o wysokim stopniu ogólności. Udowodnić w typologicznym porównaniu można tylko fakt ekwiwalencji. Niemniej jednak można wykluczyć, że odpowiednie podobieństwo lub przeciwieństwo jest „przypadkowe”, ponieważ w świecie kultury przypadek nie istnieje. Kultura, podobnie jak wszystkie systemy społeczne, jest określona przez przezwyciężenie przypadku. Niklas Luhmann nazywa to „rozwojem potencjału ludzkiego w celu zrozumienia i ograniczenia złożoności świata”17.

Również Borowy owych „błędów metodologicznych” nie przypisuje przypadkowi, lecz na przykład „najpospolitszemu wyobrażeniu, np. o piękności” ${ }^{18}$. To wyobrażenie jest kulturowo rozwinięte i tworzy związek, relację między pojęciami piękna. Jest to cecha charakterystyczna dla zasady racji bycia. Typologiczne porównanie czyni te połączenia widocznymi i je systematyzuje.

\section{Aspekty komparatystyki i funkcje społeczne}

Zestawienie aspektów komparatystyki z funkcjami społecznymi według Parsonsa uwypukla społeczne funkcje systemu literackiego. Nie w tym sensie, że jakiś utwór literacki przez swoją treść albo przez swoje przesłanie konkretnie wpływa na społeczeństwo, lecz w sensie teorii systemów Niklasa Luhmanna, która głosi, że system literacki lub system kulturowy jako całość pełnią podstawową funkcję społeczną. Wędrówka motywów i obrazów przez sferę kulturową (wpływ) przyczynia się do społecznego dopasowania. Społeczeństwo za pomocą przyjmowanych obcych chwytów albo gatunków nie podporządkowuje się obcej kulturze, lecz rozwiązuje dzięki nim swoje własne aktualne problemy społeczne. Dialog kultur przez funkcję prefiguracji przyczynia się do społecznej integracji, bo sens przeniesiony do innej przestrzeni zabiera ze sobą kulturę swego pochodzenia, a następnie stymuluje zdolność społeczeństwa docelowego do integracji. Dzięki naśladownictwu tekst przejmuje konkretną funkcję społeczną. Dlatego transfer kulturowy bezpośrednio przyczynia się do osiągnięcia odpowiedniego celu społecznego. Wreszcie formowanie semantycznych związków między pojedynczymi zjawiskami kulturowymi jest istotnym warunkiem tego, by system społeczny w ogóle mógł istnieć. Dlatego formowanie to jest decydującym powodem podtrzymywania społeczeństwa.

\footnotetext{
17 N. Luhmann, Soziologische Aufklärung, t. 1: Aufsätze zur Theorie sozialer Systeme, Opladen 1970, s. 67.

18 W. Borowy, op. cit., s. 66.
} 


\section{Bibliografia}

Auerbach Erich, Figura, „Archivum Romanicum” 1938, t. 22.

Bloom Harold, Lęk przed wptywem. Teoria poezji, tłum. Agata Bielik-Robson, Marcin Szuster, Kraków: Universitas, 2002.

Borowy Wacław, O wpływach i zależnościach w literaturze, Kraków: Krakowska Spółka Wydawnicza, 1921.

Drews Arthur, Die Christusmythe, Jena: Eugen Diederichs, 1909.

Cassirer Ernst, Substanzbegriff und Funktionsbegriff, Berlin: Bruno Cassirer, 1910 (wyd. polskie: Substancja i funkcja. Badania nad podstawowymi problemami krytyki poznania, thum. Przemysław Parszutowicz, Kęty: Wydawnictwo Marek Derewiecki, 2008).

Espagne Michel, Les transferts culturels franco-allemands, Paris: Presses universitaires de France, 1999.

Freise Matthias, Эдипальный бунт в польском и русском романтизме, [w:] Polska - Rosja: dialog kultur („Studia Rossica” t. 22), red. naukowa Alicja Wołodźko-Butkiewicz, Ludmiła Łucewicz, Warszawa: Instytut Rusycystyki Uniwersytetu Warszawskiego, 2012.

- Vier Weisen nach dem Text zu fragen, [w: Finis coronat opus. Festschrift für Walter Kroll zum 65. Geburtstag, red. Volker Bockholt, Matthias Freise, Werner Lehfeldt, Peter Meyer, Göttingen: Universitätsverlag Göttingen, 2006.

Luhmann Niklas, Soziologische Aufklärung, t. 1: Aufsätze zur Theorie sozialer Systeme, Opladen: Westdeutscher Verlag, 1970.

— Soziale Systeme. Grundriss einer allgemeinen Theorie, Frankfurt am Main: Suhrkamp, 1984.

Parsons Talcott, Szkice z teorii socjologicznej, tłum. Alina Bentkowska, wstęp Henryk Białyszewski, Warszawa: PWN, 1972.

Schopenhauer Arthur, Czworaki korzeń zasady racji dostatecznej, tłum. Józef Marzęcki, Kęty: Antyk, 2003.

Tynianow Jurij, O ewolucji literackiej, tłum. Adam Pomorski, [w: tenże, Fakt literacki, wyboru dokonała Ewa Korpała-Kirszak, Warszawa: PWN, 1978.

Wat Aleksander, Mój wiek. Pamiętnik mówiony, przedmowa Czesława Miłosza, do druku przygot. Lidia Ciołkoszowa, wyd. 2 popr., Londyn: Polonia Book Fund, 1981. 